\title{
KARAKTERISASI SERAT PANGAN DAN AKTIVITAS ANTIOKSIDAN DARI TEPUNG KULIT KAKAO (Theobroma cacao L.)
}

\author{
Ivon Palente $^{1}$, Edi Suryanto ${ }^{1}$, Lidya Irma Momuat ${ }^{1}$ \\ ${ }^{1}$ Program Studi Kimia, Fakultas Matematika dan Ilmu Pengetahuan Alam Universitas Sam Ratulangi Manado \\ Email: palenteivon@gmail.com
}

\begin{abstract}
ABSTRAK
Tujuan penelitian ini yaitu untuk mengetahui karakteristik dan aktivitas antioksidan serat pangan dari tepung kulit kakao yang diekstraksi menggunakan gelombang ultrasonik dengan perbedaan pelarut. Penelitian ini terdiri dari 3 tahap yaitu mikronisasi, ekstraksi dan karakterisasi. Hasil karakterisasi secara fisik tepung kulit kakao tanpa perlakuan (KKTP), yang diekstraksi dengan aquades (KKA) dan etanol (KKE) dengan Fourier Transform Infra Red (FTIR) tidak mengalami perubahan mendasar pada komponen utama setelah proses penggilingan dan ekstraksi secara sonikasi. Hasil difraksi sinar-X menunjukkan derajat kristalinitas KKTP $(55,58 \%)$ lebih besar daripada KKA $(54,24 \%)$ dan KKE $(53,48 \%)$. Hasil karakterisasi secara kimia menunjukkan kandungan air KKTP lebih tinggi dari KKA dan KKE, kandungan protein, karbohidrat dan lignin KKA lebih tinggi dari KKTP dan KKE. Sedangkan kandungan abu, lemak, serat pangan tak larut, serat pangan terlarut, total serat pangan, hemiselulosa dan selulosa KKE lebih tinggi dari KKTP dan KKA. Hasil pengujian aktivitas antioksidan menunjukkan ekstrak fenolik terikat $\operatorname{KKTP}(88,38 \%)$, KKA $(90,61 \%)$ dan KKE $(92,78 \%)$ lebih tinggi dibandingkan ekstrak fenolik bebas KKTP $(86,85 \%)$, KKA $(88,19 \%)$ dan KKE $(90,04 \%)$. Adapun kapasitas penangkal nitrit menunjukkan bahwa ekstrak fenolik terikat KKTP $(40,28 \%), \operatorname{KKA}(55,90 \%)$ dan KKE $(67,92 \%)$ lebih besar dibandingkan ekstrak fenolik bebas KKTP $(34,84 \%)$, KKA $(53,22 \%)$ dan KKE $(64,63 \%)$.
\end{abstract}

Kata kunci : karakterisasi, antioksidan, serat pangan, tepung kulit kakao.

\section{ABSTRACT}

The purpose of this study was to determine the characteristics and antioxidant activity of dietary fiber from cocoa husk flour extracted using ultrasonic waves with different solvents. This research consists of 3 stages, namely micronization, extraction and characterization. The results of the physical characterization of untreated cocoa husk flour (KKTP), which was extracted with distilled water (KKA) and ethanol (KKE) with Fourier Transform Infra Red (FTIR) did not experience any fundamental changes in the main components after milling and sonication extraction. The results of X-ray diffraction showed that the degree of crystallinity of KKTP $(55.58 \%)$ was greater than that of KKA (54.24\%) and KKE (53.48\%). The results of chemical characterization showed that the air content of KKTP was higher than KKA and KKE, the protein, carbohydrate and lignin content of KKA was higher than KKTP and $\mathrm{KKE}$. Meanwhile, the content of ash, fat, insoluble dietary fiber, soluble dietary fiber, total dietary fiber, hemicellulose and KKE cellulose were higher than KKTP and KKA. The antioxidant test results showed that KKTP $(88.38 \%)$, KKA $(90.61 \%)$ and KKE (92.78\%) phenolic extracts were higher than KKTP-free phenolic extracts $(86.85 \%)$, KKA $(88.19) \%)$ and KKE $(90.04 \%)$. The nitrite antidote capacity showed that the phenolic extract supported KKTP $(40.28 \%)$, KKA $(55.90 \%)$ and KKE $(67.92 \%)$ greater than KKTP-free phenolic extract $(34.84 \%)$, $\operatorname{KKA}(53,22 \%)$ and KKE (64.63\%).

Keywords: Characterization, antioxidant, dietary fiber, cocoa peel flour.

\section{PENDAHULUAN}

Indonesia merupakan negara yang kaya akan keanekaragaman hayati salah satunya yaitu tanaman kakao. Tanaman kakao dapat tumbuh disebagian besar wilayah Indonesia terutama pulau Sulawesi, Jawa, Sumatera dan Kalimantan (Departemen Perindustrian, 2007). Bagian dari tanaman kakao yang dimanfaatkan oleh masyarakat adalah bijinya. Pada tahun 2019 diperkirakan sekitar 768,77 ribu ton biji kakao dihasilkan dari perkebunan rakyat, 1,62 ribu ton dari perkebunan besar negara dan 3,81 ribu ton berasal dari perkebunan besar swasta (Badan Pusat Statistik, 2020). Tingginya produksi kakao tentu akan berbanding lurus dengan limbah kulit buah kakao. Keberadaan limbah kulit buah kakao sering kali tidak dimanfaatkan dengan baik bahkan dibiarkan begitu saja, sehingga dapat mempengaruhi kebersihan lingkungan (Departemen Perindustrian, 2007). 
Kulit kakao sebagian besar terdiri dari polisakarida yakni selulosa, lignin dan hemiselulosa (Byung dkk., 2003). Wijaya dkk. (2017), melaporkan bahwa kandungan selulosa dari kulit kakao sebesar $17,27 \%$, hemiselulosa $19,56 \%$ dan lignin 52,02\%. Selulosa, hemiselulosa dan lignin merupakan komponen penyusun dinding sel tumbuhan yang tidak terhidrolisis atau tercerna oleh enzim pencernaan manusia atau disebut juga serat pangan (Trowell dkk., 1985). Selain itu, beberapa penelitian melaporkan bahwa kulit kakao juga mengandung senyawa fitokimia yakni polifenol, flavonoid dan tanin yang berfungsi sebagai antioksidan (Padilla dkk., 2015; Sartini dkk., 2017; Vasquez, 2019). Kulit kakao dapat diolah menjadi tepung yang mengandung serat pangan dan antioksidan. Sifat fungsional tepung serat pangan mengalami peningkatan dengan adanya perlakuan mikronisasi seperti peningkatan kelarutan, kapasitas penyerapan air dan kapasitas penyerapan minyak (Raghavendra, 2004). Semakin kecil ukuran partikel, maka luas permukaannya akan semakin meningkat. Permukaan yang lebih luas memungkinkan interaksi yang lebih besar dengan pelarut (Savjani dkk., 2012).

Pada tahun terakhir ini, teknik ultrasonikasi telah digunakan secara luas untuk ekstraksi senyawa aktif (Suryanto, 2020). Ultrasonic-assisted extraction (UAE) adalah salah satu metode ektraksi berbantu ultrasonic (Sholihah dkk., 2017). Penggunaan ultrasonik dalam proses ekstraksi senyawa organik pada tanaman dengan menggunakan pelarut organik dapat berlangsung lebih cepat karena dinding sel dari bahan dipecah dengan getaran ultrasonik sehingga kandungan yang ada di dalamnya dapat keluar dengan mudah (Mason, 1990). Studi menggunakan UAE untuk peningkatan rendemen dan efektivitas ekstraksi sudah banyak dilakukan, seperti pada ekstraksi gingerol dari jahe (Balachandran dkk., 2006), ekstraksi polifenol, asam amino dan kafein dari teh hijau (Xia dkk., 2006), serta ekstraksi fenolik, flavonoid dan tanin dari daun jambu biji, dengan aktivitas antioksidan yang tinggi (Sekarsari dkk., 2019). Berdasarkan uraian tersebut, penelitian ini bertujuan untuk mempelajari karaktersitik serat pangan dan aktivitas antioksidan dari tepung kulit kakai yang diekstraksi menggunakan sonikasi dengan perbedaan pelarut.

\section{BAHAN DAN METODE}

Kulit kakao diperoleh dari Desa Domoga, Kabupaten Bolaang Mongondow, Sulawesi Utara. Bahan-bahan kimia seperti etanol, aseton, reagen Folin-Ciocalteu, natrium karbonat, natrium hidroksida, natrium nitrit, asam sulfat, asam sulfanilat, asam klorida dan buffer fosfat, sedangkan 1,1-difenil-2-pikrilhidrazil (DPPH), enzim $\alpha$-amilase, enzim amiloglukosidase dan N(1-Naphthyl) ethylenediamine diperoleh dari Sigma Aldrich

\section{Preparasi sampel}

Sampel kulit kakao yang diperoleh dari desa Pinonobatuan, Dumoga Timur, Kabupaten Bolaang Mongondow, Sulawesi Utara dipotong kecil-kecil lalu direbus selama 30 menit dan dikeringkan dalam oven pada suhu $50-60{ }^{\circ} \mathrm{C}$ selama 3 hari. Setelah itu, sampel dihancurkan dengan blender kemudian dihaluskan menggunakan alat milling (Fomac tipe FCTZ200 tegangan $220 \mathrm{~V}$ daya $1 \mathrm{KW}$ frekuensi 50$60 \mathrm{~Hz}$ kecepatan putar $28.000 \mathrm{rpm}$ ), lalu diayak menggunakan ayakan 200 mesh $(75 \mu \mathrm{m})$. Sampel yang diperoleh dari ayakan 200 mesh disimpan dalam wadah kedap udara sebelum diekstraksi dan dianalisis.

\section{Ekstraksi}

Tepung kulit kakao (200 mesh) diekstraksi menggunakan teknik ekstraksi sonikasi (Krisbow frekuensi $37 \mathrm{kHz}$, daya 50 watt), dengan pelarut etanol $80 \%$ dan aquades. Masing-masing sebanyak $5 \mathrm{~g}$ tepung kulit kakao dimasukkan ke dalam gelas piala dan ditambahkan pelarut kemudian disonikasi selama 3 jam. Setelah disonikasi, sampel disaring sehingga diperoleh filtrat dan residu. Residu kemudian keringkan dalam oven pada suhu 50-60 ${ }^{\circ} \mathrm{C}$. Residu yang telah kering selanjutnya di giling sehingga diperoleh tepung kulit kakao.

\section{Karakterisasi fisik}

Tepung kulit kakao dikarakterisasi secara fisik menggunakan Fourier Transform Infra Red (FT-IR, Shimadzu) untuk mengetahui gugus fungsi dan X-Ray Diffraction (X-RD, Bruker). untuk mengetahui derajat kristalinitas.

\section{Karakterisasi kimia}

Analisis proksimat untuk mengetahui komposisi kimia dari tepung kulit kakao, yang 
meliputi uji kadar air, kadar abu, kadar lemak dan kadar protein menggunakan metode Sudarmadji (1997), serta kadar karbohidrat menggunakan metode by difference (SNI 01-2891-1992). Selanjutnya analisis kadar hemiselulosa, selulosa, lignin dari tepung kulit kakao dilakukan dengan metode fraksinasi dari Chesson (1978) dan Datta (1981). Untuk pengujian serat pangan menggunakan metode AOAC (1995).

\section{Ekstraksi fenolik bebas dan fenolik terikat}

Sebanyak $4 \mathrm{~g}$ tepung kulit kakao tanpa perlakuan, tepung kulit kakao diekstraksi dengan akuades dan tepung kulit kakao diekstraksi dengan etanol $80 \%$ masing-masing diekstraksi menggunakan teknik ekstraksi sonikasi selama 3 jam. Setelah itu, disaring menggunakan kertas saring sehingga diperoleh filtrat dan residu. Filtrat kemudian dievaporasi pada suhu $50{ }^{\circ} \mathrm{C}$. Ekstrak pekat yang diperoleh ditimbang dan disimpan sebagai ekstrak fenolik bebas tanpa perlakuan (EFBTP), ekstrak fenolik bebas akuades (EFBA) dan ekstrak fenolik bebas etanol (EFBE). Setelah ekstraksi fenolik bebas, $3 \mathrm{~g}$ residu dari masing-masing fenolik bebas dihidrolisis dengan $60 \mathrm{~mL} \mathrm{NaOH} 2 \mathrm{M}$, diaduk dan didiamkan pada suhu kamar selama 2 jam. Selanjutnya, campuran dinetralkan dengan $\mathrm{HCl} 6$ M sampai pH 6 dan diekstraksi dengan etil asetat sampai bening. Fraksi etil asetat dievaporasi pada suhu $40{ }^{\circ} \mathrm{C}$ dan dikeringkan dalam oven sehingga diperoleh ekstrak fenolik terikat (EFTTP), ekstrak fenolik terikat akuades (EFTA) dan ekstrak fenolik terikat etanol (EFTE). Ekstrak yang diperoleh ditimbang dan disimpan sebelum dianalisis kandungan total fenolik, kapasitas penangkal radikal bebas dan kapasitas penangkal nitrit.

\section{Penentuan kandungan total fenolik}

Kandungan total fenolik dalam tepung kulit kakao ditentukan menggunakan metode Jeong dkk. (2004). Sebanyak $0,1 \mathrm{~mL}$ masingmasing ekstrak $1000 \mu \mathrm{g} / \mathrm{mL}$ dari ekstrak fenolik bebas dan ekstrak fenolik terikat kulit kako dimasukkan ke dalam tabung reaksi, lalu ditambahkan $0,1 \mathrm{~mL}$ reagen Folin-Ciocalteu $50 \%$. Campuran tersebut divortex selama 3 menit, lalu ditambahkan $2 \mathrm{~mL}$ larutan natrium karbonat $2 \%$. Selanjutnya campuran diinkubasi dalam ruang gelap selama 30 menit. Absorbansinya dibaca pada panjang gelombang $750 \mathrm{~nm}$ dengan spektrofotometer UV-Vis (Shimadzu 1800). Hasilnya dinyatakan sebagai ekuivalen asam galat dalam $\mu \mathrm{g} / \mathrm{mL}$ ekstrak. Kurva kalibrasi dipersiapkan dengan cara yang sama menggunakan asam galat sebagai standar.

\section{Penentuan aktivitas penangkal radikal bebas}

Penentuan aktivitas penangkal radikal bebas tepung kulit kakao ditentukan dengan metode Burda \& Oleszeck (2001). Sebanyak 0,5 $\mathrm{mL}$ masing-masing ekstrak fenolik bebas dan ekstrak fenolik terikat kulit kakao dimasukkan ke dalam tabung reaksi, lalu ditambahkan dengan 1,5 $\mathrm{mL}$ larutan 1,1-difenil-2-pikrilhidrazil (DPPH) dan divortex selama 2 menit. Berubahnya warna larutan dari ungu ke kuning menunjukan efisiensi penangkal radikal bebas. Selanjutnya pada 5 menit terakhir menjelang 30 menit inkubasi, absorbansinya diukur pada panjang gelombang $517 \mathrm{~nm}$ dengan menggunakan spektrofotometer UV-Vis. Aktivitas penangkal radikal bebas (APRB) dihitung sebagai presentase berkurangnya warna DPPH dengan menggunakan persamaan:

$$
\text { APRB }=\left(1-\frac{\text { absorbansi sampel }}{\text { absorbansi kontrol }}\right) \times 100 \%
$$

\section{Penentuan aktivitas penangkal nitrit}

Kapasitas penangkal ion nitrit ditentukan menggunakan metode Zhang dkk. (2009). Sebanyak $2 \mathrm{~mL}$ natrium nitrit $5 \mathrm{mg} / \mathrm{L}$ dicampur dengan $3 \mathrm{~mL}$ masing-masing ekstrak fenolik bebas dan ekstrak fenolik terikat dalam labu 25 $\mathrm{mL}$ pada suhu kamar selama 30 menit. Campuran ditambahkan dengan $1 \mathrm{~mL}$ asam sulfanilat $0,4 \%$, lalu distirer selama 5 menit diikuti penambahan $0,5 \mathrm{~mL} \mathrm{~N}$-(1-naphthyl)ethylenediamine $0,1 \%$ dan volume disesuaikan menjadi $25 \mathrm{~mL}$ dengan aquades. Larutan didiamkan selama 15 menit dan diukur absorbansi menggunakan Spektrofotometer UV-Vis pada $\lambda 538 \mathrm{~nm}$. Kapasitas penangkal ion nitrit (\%) dihitung menggunakan rumus:

Kapasitas penangkal nitrit (\%)

$$
=\left(\frac{\mathrm{A}_{0}-\left(\mathrm{A}_{1}-\mathrm{A}_{2}\right)}{\mathrm{A}_{0}}\right) \times 100 \%
$$

Keterangan: $\mathrm{A} 0=$ absorbansi $\mathrm{NaNO}_{2} ; \mathrm{A} 1=$ absorbansi $\mathrm{NaNO}_{2}$ dan ekstrak; $\mathrm{A}_{2}=$ absorbansi ekstrak.

\section{HASIL DAN PEMBAHASAN}

\section{Rendemen tepung kulit kakao}

Sampel yang digunakan dalam 
penelitian ini adalah kulit kakao. Kulit kakao dipotong kecil-kecil lalu direbus selama 30 menit untuk menghilangkan getah dan enzim fenolase. Selanjutnya, sampel dikeringkan dalam oven, dihaluskan dan diayak menggunakan ayakan 200 mesh. Sampel yang lolos ayakan 200 mesh diekstraksi menggunakan sonikator dalam pelarut yang berbeda yaitu aquades dan etanol $80 \%$. Nilai rendemen ekstrak tepung kulit kakao yang diekstraksi dengan pelarut aquades lebih sedikit daripada etanol $(93,65 \%)$. Dari data tersebut dapat disimpulkan bahwa rendemen ekstrak dalam pelarut etanol lebih besar dibandingkan pelarut aquades. Hal ini menunjukkan bahwa pelarut etanol merupakan pelarut yang baik untuk mengekstrak tepung kulit kakao daripada aquades. Penggunaan pelarut etanol karena merupakan pelarut universal dimana dapat melarutkan hampir semua senyawa organik yang ada pada sampel, baik senyawa polar maupun non polar (Noviyanti, 2016).

\section{Komposisi kimia tepung kulit kakao}

Analisis proksimat tepung kulit kakao meliputi analisis kadar air, kadar abu, kadar protein, kadar lemak dan kadar karbohidrat. Hasil analisis proksimat yang merupakan rata-rata dari dua kali pengulangan ditunjukkan pada Tabel 1 .

Tabel 1. Hasil analisis komposisi kimia tepung kulit kakao

\begin{tabular}{llll}
\hline \multicolumn{3}{c}{ Komposisi } & \multicolumn{2}{c}{ KKTP } & KKA & KKE \\
kimia (\%) & $7,74 \pm 2,30^{\mathrm{a}}$ & $5,99 \pm 0,24^{\mathrm{a}}$ & $6,80 \pm 1,80^{\mathrm{a}}$ \\
\hline Air & $4,27 \pm 0,11^{\mathrm{a}}$ & $4,16 \pm 0,35^{\mathrm{a}}$ & $4,47 \pm 0,78^{\mathrm{a}}$ \\
Abu & $5,80 \pm 0.08^{\mathrm{a}}$ & $6,06 \pm 0.09^{\mathrm{a}}$ & $5,34 \pm 0.08^{\mathrm{b}}$ \\
Protein & $0,49 \pm 0,04^{\mathrm{a}}$ & $0,55 \pm 0,18^{\mathrm{a}}$ & $0,75 \pm 0,06^{\mathrm{a}}$ \\
Lemak & $81,70 \pm 2,30^{\mathrm{a}}$ & $83,23 \pm 0,38^{\mathrm{a}}$ & $82,64 \pm 1,17^{\mathrm{a}}$ \\
Karbohidrat & $2,16 \pm 0,04^{\mathrm{a}}$ & $2,75 \pm 0,07^{\mathrm{b}}$ & $3,23 \pm 0,03^{\mathrm{c}}$ \\
Serat pangan terlarut & $57,71 \pm 0.40^{\mathrm{a}}$ & $62,43 \pm 0,03^{\mathrm{b}}$ & $64,83 \pm 0,53^{\mathrm{c}}$ \\
Serat pangan tak larut & $59,87 \pm 0,44^{\mathrm{a}}$ & $65,18 \pm 0,04^{\mathrm{b}}$ & $68,06 \pm 0,50^{\mathrm{c}}$ \\
Serat pangan total & & & \\
\hline
\end{tabular}

Keterangan : KKTP (kulit kakao tanpa perlakuan), KKA (kulit kakao yang diekstraksi dengan aquades), KKE (kulit kakao yang diekstraksi dengan etanol.

Berdasarkan Tabel 1 kandungan kadar air tertinggi terdapat pada sampel KKTP yaitu sebesar 7,74\%, kemudian KKE sebesar 6,80\% dan KKA sebesar 5,99\%. Kadar air merupakan banyaknya air yang terkandung dalam bahan dan dinyatakan dalam persen (Kusuma, 2015). Hasil analisis statistik menunjukkan bahwa kadar air dari ketiga sampel tidak berbeda nyata $(\mathrm{p}>0,05)$. $\mathrm{Hal}$ ini kemungkinan disebabkan oleh waktu dan suhu pengeringan yang sama untuk semua sampel kulit kakao. Penentuan kadar abu bertujuan untuk mengetahui besarnya kandungan mineral yang terdapat dalam sampel, berdasarkan bobot kering. Abu adalah zat anorganik sisa hasil pembakaran suatu bahan organik (Nurhidayah dkk., 2019). Penentuan kadar abu berhubungan erat dengan kandungan mineral dan kemurnian yang terdapat dalam suatu bahan (Hayati dkk., 2012). Hasil analisis kadar abu pada sampel KKTP, KKA dan KKE berturut-turut sebesar $4,27 \%$; 4,16\%; $4,47 \%$. Hasil analisis statistik menunjukkan bahwa Kadar abu dari ketiga sampel tidak berbeda nyata $(p>0,05)$. Kadar abu pada penelitian ini lebih tinggi daripada kadar abu pada penelitian Silfia dkk. (2017), sebesar 3,45\%. Semakin tinggi kadar abu maka semakin tinggi pula kadar mineral dalam bahan pangan tersebut (Winarno, 1992). Berdasarkan Tabel 1 kandungan protein dari KKTP, KKA dan KKE berturut-turut sebesar 5,80\%; 6,06\%; 5,34\%. Kandungan protein dari KKE lebih rendah daripada KKTP dan KKA, serta tidak ada perbedaan yang nyata antara KKTP dan KKA $(p>0,05)$. Kandungan protein pada KKA lebih tinggi dari KKE diduga karena aquades lebih banyak mengikat molekul protein daripada etanol. Hal ini sejalan dengan pendapat Yoshito (2006), yang menyatakan bahwa banyaknya jumlah bahan ekstrak yang terlarut pada aquades disebabkan oleh banyaknya ikatan hidrogen yang terbentuk antara aquades dan molekul lain seperti protein sedangkan pada etanol jumlah ikatan 
hidrogen terbentuk sedikit karena adanya ikatan hidrokarbon yang tidak dapat membentuk ikatan hidrogen. Lemak adalah senyawa organik yang terdiri atas unsur-unsur karbon $(\mathrm{C})$, hidrogen $(\mathrm{H})$ dan oksigen $(\mathrm{O})$ yang dapat larut dalam pelarutpelarut tertentu dan merupakan salah satu unsur penting dalam bahan pangan yang berfungsi sebagai sumber energi (Sediaoetama, 1985). kandungan lemak dari KKTP, KKA dan KKE berturut-turut adalah $0,49 \% ; 0,55 \% ; 0,75 \%$. Kandungan lemak pada KKTP, KKA dan KKE tidak berbeda nyata $(p>0,05)$. Hasil ini menunjukkan bahwa perbedaan pelarut dan sonikasi dalam proses ekstraksi tidak mempengaruhi kandungan lemak dalam tepung kakao. Hasil ini menunjukkan bahwa perbedaan pelarut dan sonikasi dalam proses ekstraksi tidak mempengaruhi kandungan lemak dalam tepung kakao. Pada penelitian ini kandungan karbohidrat non-serat dihitung dengan perhitungan carbohydrate by difference yaitu dengan melibatkan kadar air, kadar abu, kadar lemak dan kadar protein. Tingginya nilai karbohidrat pada penelitian ini diduga karena terdapat komponen karbohidrat termasuk serat yang tidak terdeteksi dengan analisis komposisi kimia. Menurut Yenrina (2015), metode perhitungan karbohidrat ini mengukur kadar karbohidrat secara kasar, baik karbohidrat tercerna seperti pati dan gula, maupun karbohidrat tidak tercerna seperti pektin, hemiselulosa dan selulosa, serta non-karbohidrat seperti lignin.

Berdasarkan Tabel 1, hasil uji statistik menunjukkan bahwa terdapat perbedaan yang nyata kandungan serat pangan larut dan tak larut, serta serat pangan total antara ke-3 perlakuan tersebut $(p<0,05)$. KKE mengandung serat pangan total tertinggi, diikuti KKA dan KKTP. Pola yang sama juga terdapat pada kandungan serat larut dan tidak larut. Perbedaan kandungan serat pangan pada ketiga sampel diduga karena adanya perlakuan ekstraksi menggunakan gelombang ultrasonik pada sampel KKA dan KKE yang menyebabkan kandungan serat pangannya lebih tinggi daripada KKTP. Pradana dkk. (2017), menyatakan bahwa gelombang ultrasonik pada ekstraksi padat cair membentuk gelembung kavitasi yang memiliki kemampuan dalam memecah struktur matriks dari dinding sel tanaman termasuk polimer dari serat seperti lignoselulosa.

\section{Kandungan hemiselulosa, selulosa dan lignin} Berdasarkan Tabel 2, menunjukkan bahwa kandungan tertinggi pada setiap sampel yaitu lignin. Hal ini sejalan dengan penelitian yang dilakukan (Wijaya dkk., 2017; Rambat dkk., 2015; Irwanto dkk., 2016) yang juga melaporkan bahwa pada kulit kakao, kandungan lignin lebih tinggi daripada selulosa dan hemiselulosa. Perbedaan kandungan hemiselulosa, selulosa dan ligin pada sampel diduga disebabkan karena adanya perlakuan ekstraksi sonikasi. Tujuan dari ekstraksi secara sonikasi yang memanfaatkan gelombang ultrasonik adalah untuk membuka struktur lignoselulosa agar selulosa menjadi lebih mudah diakses oleh enzim yang memecah polimer polisakarida menjadi monomer gula sehingga kadar selulosa akan meningkat sedangkan kadar lignin akan semakin turun (Mosier dkk., 2005).

Tabel 2. Kandungan hemiselulosa, selulosa dan lignin

\begin{tabular}{llllc}
\hline \multirow{2}{*}{ Kandungan } & \multicolumn{3}{l}{ Sampel } & \\
\cline { 3 - 4 } & KKTP & KKA & KKE \\
\hline \multirow{2}{*}{$(\%)$} & Hemiselulosa & $12,19 \pm 0,10^{\mathrm{a}}$ & $13,08 \pm 0,02^{\mathrm{b}}$ & $13,77 \pm 0,13^{\mathrm{c}}$ \\
& & & & 11,32 \\
& Selulosa (\%) & $8,25 \pm 0,06^{\mathrm{a}}$ & $11,11 \pm 0,07^{\mathrm{b}}$ & $\pm 0,03^{\mathrm{c}}$ \\
& Lignin (\%) & $35,18 \pm 0,13^{\mathrm{a}}$ & $37,17 \pm 0,22^{\mathrm{b}}$ & $35,60 \pm 0,27^{\mathrm{a}}$ \\
\hline
\end{tabular}

Singkatan seperti pada Tabel 1.

\section{Spekra IR}

Berdasarkan Gambar 1, spektrum dari standar selulosa (MKS) menunjukkan adanya serapan yang kuat pada panjang gelombang $3371,57 \mathrm{~cm}^{-1}$, sedangkan pada Gambar 6 serapan yang kuat dari KKTP berada pada panjang gelombang $3421,64 \mathrm{~cm}^{-1}$, KKA pada panjang gelombang $3402,26 \mathrm{~cm}^{-1}$ dan KKE berada pada panjang gelombang $3410,15 \mathrm{~cm}^{-1}$. Daerah serapan $3200-3550 \mathrm{~cm}^{-1}$ mengindikasikan 
adanya renggangan $\mathrm{OH}$ dari gugus hidroksil yang berasal dari selulosa (Milovanovic dkk., 2016). Spektrum dari selulosa standar menunjukkan serapan pada panjang gelombang $2900,94 \mathrm{~cm}^{-1}$ sedangkan spektra dari KKTP, KKA dan KKE menunjukkan serapan pada bilangan gelombang $2931,80 \mathrm{~cm}^{-1}$. Daerah serapan $2480-3000 \mathrm{~cm}^{-1}$ menunjukkan vibrasi $\mathrm{C}-\mathrm{H}$ dari selulosa yang mengindikasikan kehadiran senyawa polisakarida (Abbasi dkk., 2016). Pada sampel KKA dan KKE terdapat serapan pada bilangan gelombang 1442,75 $\mathrm{cm}^{-1}$. Menurut Shanmugarajah dkk. (2015), daerah serapan sekitar $1400 \mathrm{~cm}^{-1}$ menandakan adanya ikatan $\mathrm{CH}_{2}$. Hal ini sesuai dengan spektrum pada MKS yang memiliki serapan pada $1427,32 \mathrm{~cm}^{-1}$.
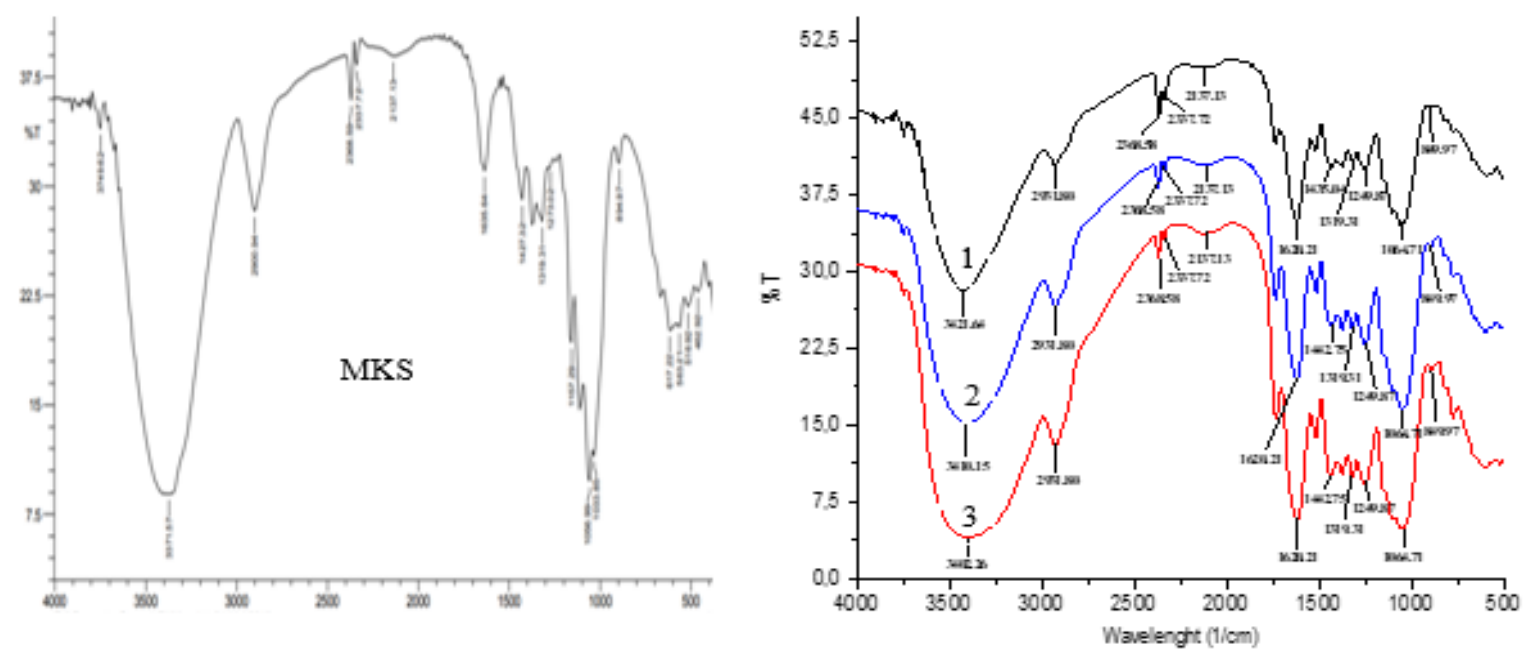

Gambar 1. Spektrum FT-IR mikrokristal selulosa (MKS) dan 1. TPKK, 2. EKK dan 3. AKK

Pada ketiga sampel (KKTP, KKA dan KKE) terdapat serapan pada bilangan gelombang $1249,87 \mathrm{~cm}^{-1}$. Menurut Reddy dkk. (2005), puncak serapan antara 1200-1300 cm ${ }^{-1}$ menandakan adanya lignin. Secara umum ketiga sampel memiliki bilangan gelombang yang relatif sama, dan diduga disebabkan tidak terjadi perubahan gugus fungsi yang signifikan selama proses mikronisasi. Namun demikian, perbedaan panjang gelombang menunjukkan adanya degradasi pada ketiga sampel. Beberapa penelitian melaporkan bahwa kekuatan mekanik selama penggilingan dapat memutus ikatan hidrogen intramolekul dan mungkin dikaitkan dengan degradasi selulosa (Zhao dkk., 2015; Ma $\& \mathrm{Mu}, 2016)$.

\section{X-Ray Diffraction (XRD)}

Berdasarkan Gambar 2 dan Tabel 3, difraktogram sinar-X dari KKTP menunjukkan puncak $2 \theta$ yang menonjol sekitar $14,74^{\circ}$ dan $21,32^{\circ}$, dengan intensitas sebesar 372/444 dan nilai FWHM sebesar $1,98 / 1,98$, pada KKA puncak $2 \theta$ yang menonjol sekitar $14,9^{\circ}$ dan $21,30^{\circ}$ dengan intensitas sebesar $422 / 479$ dan nilai FWHM sebesar $1,98 / 1,98$, pada KKE puncak $2 \theta$ yang menonjol sekitar $15,04^{\circ}$ dan $21,84^{\circ}$ dengan intensitas sebesar 532/597 dan nilai FWHM sebesar 1,98/1,98 sedangkan difraktogram sinar-X dari mikrokristalin selulosa menunjukkan puncak $2 \theta$ yang menonjol sekitar $15,06^{\circ}$ dan $22,64^{\circ}$ dengan puncak intensitas sebesar 528/1262 dan nilai FWHM sebesar 1,98/1,79. Pola difraktogram sinar-X dari KKTP, KKA, dan KKE jika dibandingkan dengan pola difraktogram dari mikrokristalin selulosa sebagai standar menunjukkan perbedaan pada intensitas dan puncak $2 \theta$. Perbedaan intensitas dan puncak $2 \theta$ diduga dipengaruhi oleh perlakuan dengan pelarut dan mikronisasi. Perlakuan dengan pelarut dan mikronisasi menghasilkan selulosa yang amorf. Hal ini sesuai dengan penelitian Troedec dkk. (2008), yang menyatakan bahwa bagian amorf dari selulosa ditunjukkan pada kisaran puncak difraksi $16^{\circ}$ sedangkan bagian kristal dari selulosa ditunjukkan pada kisaran puncak difraksi $22^{\circ}$. 

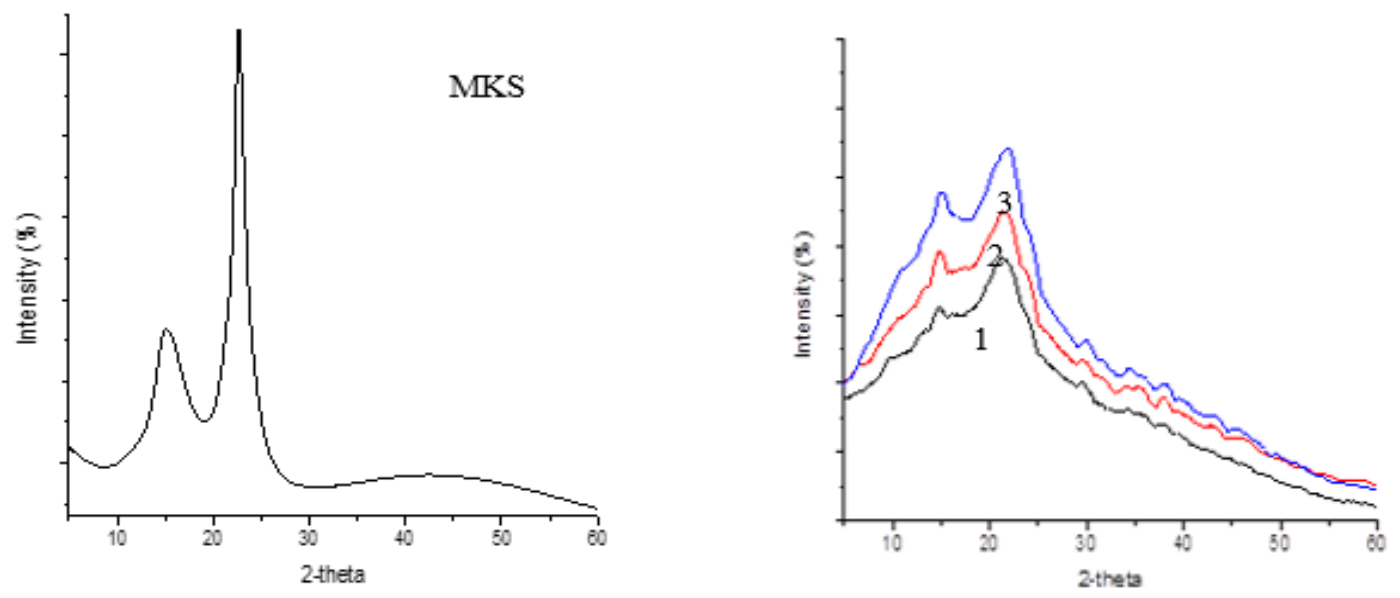

Gambar 2. Pola XRD tepung mikrokristalin selulosa dan tepung kulit kakao 1. KKTP, 2. KKA, 3. KKE dan mikrokristal selulosa (MKS)

Tabel 3. Karakteristik kristalinitas tepung kulit kakao dan mikrokristalin selulosa

\begin{tabular}{lc}
\hline Sampel & $\begin{array}{c}\text { Kristanilitas } \\
(\%)\end{array}$ \\
\hline KKTP & 55,58 \\
KKA & 54,24 \\
KKE & 53,48 \\
MKS & 66,27 \\
\hline
\end{tabular}

Singkatan seperti pada Tabel 1. dan MKS (mikrokristalin selulosa).

Pada Tabel 5 kristalinitas yang diperoleh pada KKTP, KKA dan KKE berturut-turut 55,58\%; $52,42 \% ; 53,48 \%$. Jika dibandingkan dengan serbuk mikrokristalin selulosa dengan derajat kristalinitas sebesar 66,27\% kristalinitas dari KKTP, KKA dan KKE lebih rendah. Hal ini menunjukkan bahwa tingkat kemurnian serat selulosa dari tanaman lebih rendah. Ini sesuai dengan penelitian Suryanto (2017), yang menyatakan bahwa proses pemurnian serat dari tanaman mempengaruhi kristalinitas dari serat selulosa yaitu menyebabkan serat dari tanaman memiliki kristalinitas rendah yang menunjukkan tingkat kemurnian yang rendah.
Ekstraksi dan kandungan fenolik

Ekstraksi merupakan proses pemisahan suatu komponen dari campurannya dengan menggunakan pelarut yang sesuai. Metode ekstraksi yang digunakan dalam penelitian ini adalah sonikasi dan hidrolisis dengan asam dan basa. Ekstraksi KKTP, KKA, dan KKE dengan pelarut etanol digunakan untuk mendapatkan ekstrak fenolik bebas sedangkan residu hasil ekstraksi fenolik bebas dihidrolisis dengan asam dan basa untuk mendapatkan ekstrak fenolik terikat.

Tabel 4. Rendemen ekstraksi dan kandungan total fenolik dari tepung kulit kakao

\begin{tabular}{lccccc}
\hline \multirow{3}{*}{ Sampel } & \multicolumn{3}{c}{ Rendemen } & \multicolumn{3}{c}{ Kandungan fenolik } \\
\cline { 2 - 6 } & $\begin{array}{c}\text { FB } \\
(\%)\end{array}$ & $\begin{array}{c}\text { FT } \\
(\%)\end{array}$ & $\begin{array}{c}\text { Fenolik bebas } \\
(\mu \mathrm{g} / \mathrm{mL})\end{array}$ & $\begin{array}{c}\text { Fenolik terikat } \\
(\mu \mathrm{g} / \mathrm{mL})\end{array}$ & $\begin{array}{c}\text { Total fenolik } \\
(\mu \mathrm{g} / \mathrm{mL})\end{array}$ \\
\hline KKTP & 75,04 & 78,05 & $84,80 \pm 0,58^{\mathrm{a}}$ & $90,66 \pm 0,23^{\mathrm{a}}$ & $175,50 \pm 0,41^{\mathrm{a}}$ \\
KKA & 77,84 & 78,06 & $90,08 \pm 0,35^{\mathrm{b}}$ & $97,79 \pm 0,58^{\mathrm{b}}$ & $187,87 \pm 0,47^{\mathrm{b}}$ \\
KKE & 80,43 & 82,43 & $97,54 \pm 0,46^{\mathrm{c}}$ & $102,70 \pm 1,04^{\mathrm{c}}$ & $200,24 \pm 0,75^{\mathrm{c}}$ \\
\hline
\end{tabular}

Singkatan seperti pada Tabel 1. (FB: fenolik bebas dan FT: fenolik terikat)

Berdasarkan Tabel 4, dapat diketahui

bahwa KKE memiliki persentase rendemen tertinggi dibandingkan dengan KKA dan KKTP.
Rendemen fenolik terikat pada semua sampel memiliki persentase lebih tinggi dibandingkan dengan fenolik bebas. Tingginya nilai rendemen 
fenolik terikat pada semua sampel menunjukkan bahwa masih terdapat kandungan fenolik di dalam residu hasil ekstraksi sonikasi yang tidak terekstraksi menggunakan metode ekstraksi sonikasi. Hal ini diduga disebabkan oleh adanya ikatan glikosidik yang menyebabkan senyawa fenolik tidak mudah diekstraksi dengan pelarut. Sedangkan ekstraksi dengan hidrolisis yang menggunakan asam dan basa dapat memutuskan ikatan antara senyawa fenolik dengan karbohidrat. Zhang dkk. (2009), menyatakan bahwa ekstraksi dengan metode sonikasi menghasilkan rendemen yang lebih besar dan waktu ekstraksi yang lebih cepat dibandingkan dengan metode ekstraksi konvensional seperti maserasi dan soxhletasi. Menurut Suryanto \& Suoth (2020), fenomena kavitasi akustik yang dihasilkan oleh gelombang ultrasonik melalui sistem pelarut dapat meningkatkan pelepasan metabolit dari matriks kepada pelarut. Pada Tabel 4, diketahui bahwa kandungan fenolik tertinggi sampel terdapat pada ekstrak fenolik terikat KKE $(102,70 \mu \mathrm{g} / \mathrm{mL})$ diikuti ekstrak fenolik terikat KKA $(97,79 \mu \mathrm{g} / \mathrm{mL})$, ekstrak fenolik bebas KKE $(97,54 \mu \mathrm{g} / \mathrm{mL})$, ekstrak fenolik terikat KKTP $(90,66 \mu \mathrm{g} / \mathrm{mL})$, ekstrak fenolik bebas KKA $(90,08 \mu \mathrm{g} / \mathrm{mL})$ dan yang terendah yaitu ekstrak fenolik bebas KKTP $(84,84 \mu \mathrm{g} / \mathrm{mL})$. Dari data tersebut menunjukkan bahwa ekstrak fenolik terikat pada setiap sampel memiliki kandungan fenolik yang lebih tinggi dari ekstrak fenolik bebas, hal tersebut diduga bahwa pada sampel dari sisa penyaringan selama diekstraksi menggunakan basa masih mengandung bahan aktif terutama senyawa fenolik yang terkandung dalam residu tersebut. Hal ini sesuai dengan penelitian Parra dkk. (2007), yang menyatakan bahwa saat dilakukan proses hidrolisis dari residu hasil ekstrak (ekstrak fenolik terikat) ternyata masih banyak kandungan senyawa fenolik yang terkandung dalam residu tersebut. Selain itu, Karepu dkk. (2020), juga melaporkan bahwa kandungan total fenolik di dalam ekstrak fenolik terikat lebih tinggi dibandingkan dengan ekstrak fenolik bebas. Untuk pengujian fenolik terikat dilakukan penambahan pelarut etil asetat karena etil asetat dapat melarutkan senyawa fenolik yang lebih banyak sehingga menunjukkan sebagian besar senyawa fenolik yang merupakan senyawa bersifat semipolar.

\section{Aktivitas penangkal radikal bebas}

Pada Gambar 3. menunjukkan bahwa persentase penangkal radikal bebas pada ekstrak fenolik terikat pada masing-masing sampel lebih tinggi dibandingkan ekstrak fenolik bebas. Hal ini kemungkinan disebabkan residu dari ekstrak fenolik bebas yang dihidrolisis dengan basa dan asam masih mengandung fitokimia antioksidan. Mekanisme senyawa fenolik sebagai antioksidan yaitu melalui kemampuan gugus fenol untuk berpasangan dengan radikal bebas dengan cara mendonorkan atom hidrogennya melaui transfer elektron, proses ini mengubah fenol menjadi radikal fenoksil. Radikal fenoksil ini dapat menstabilkan diri melalui proses resonansi sehingga tidak terjadi reaksi berantai pembentukan radikal (Janeiro \& Brett, 2004). Beberapa penelitian lain yang menunjukkan adanya hubungan antara kandungan total fenolik dengan kapasitas penangkal radikal bebas yaitu penelitian yang dilakukan oleh (Momuat dkk., 2015; Suryanto \& Momuat, 2017; Padmawati, 2020).

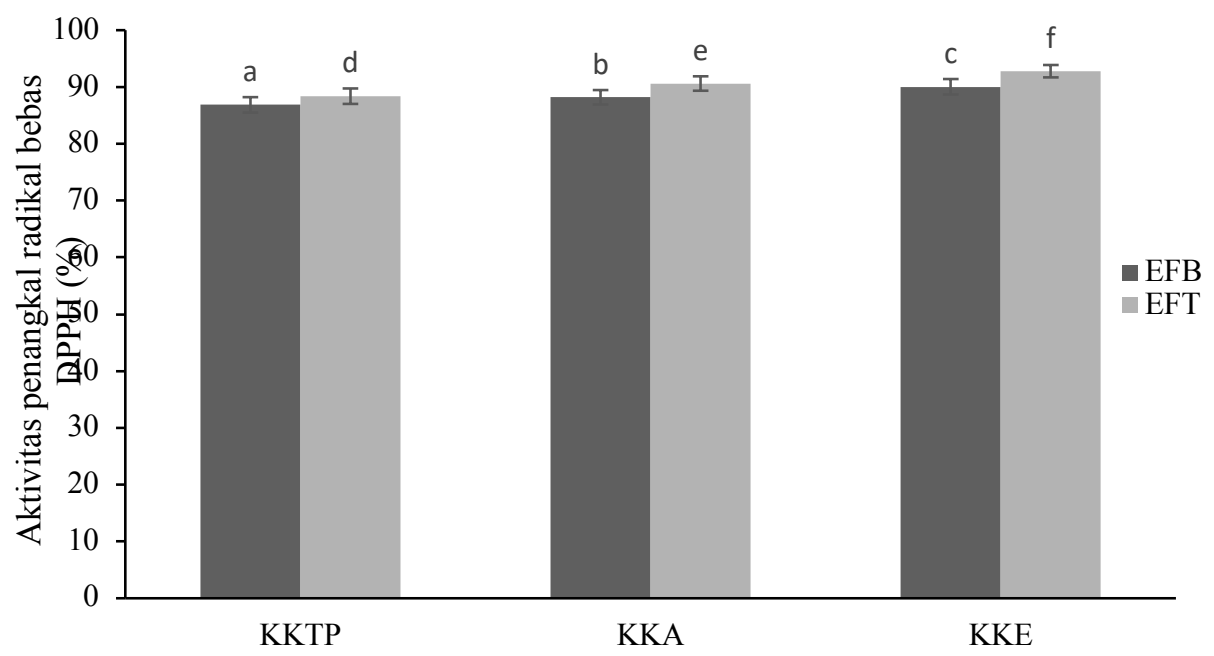

Gambar 3. Aktivitas penangkal radikal bebas DPPH ekstrak fenolik bebas (EFB) dan ekstrak fenolik terikat (EFT) dari tepung kulit kakao KKTP, KKA dan KKE (Singkatan seperti pada Tabel 1.) 


\section{Kapasitas penangkal nitrit}

Nitrit merupakan ion reaktif yang dapat bereaksi dengan amina sekunder pada asam dan membentuk senyawa nitrosamine yang karsinogenik. Dimana reaksi ini berlangsung dalam usus atau lambung. Senyawa nitrosamine yang terbentuk dapat dihambat oleh senyawa fenolik. Gambar 4 menunjukkan kapasitas penangkal nitrit ekstrak KKTP, KKA dan KKE konsentrasi $1000 \mu \mathrm{g} / \mathrm{mL}$

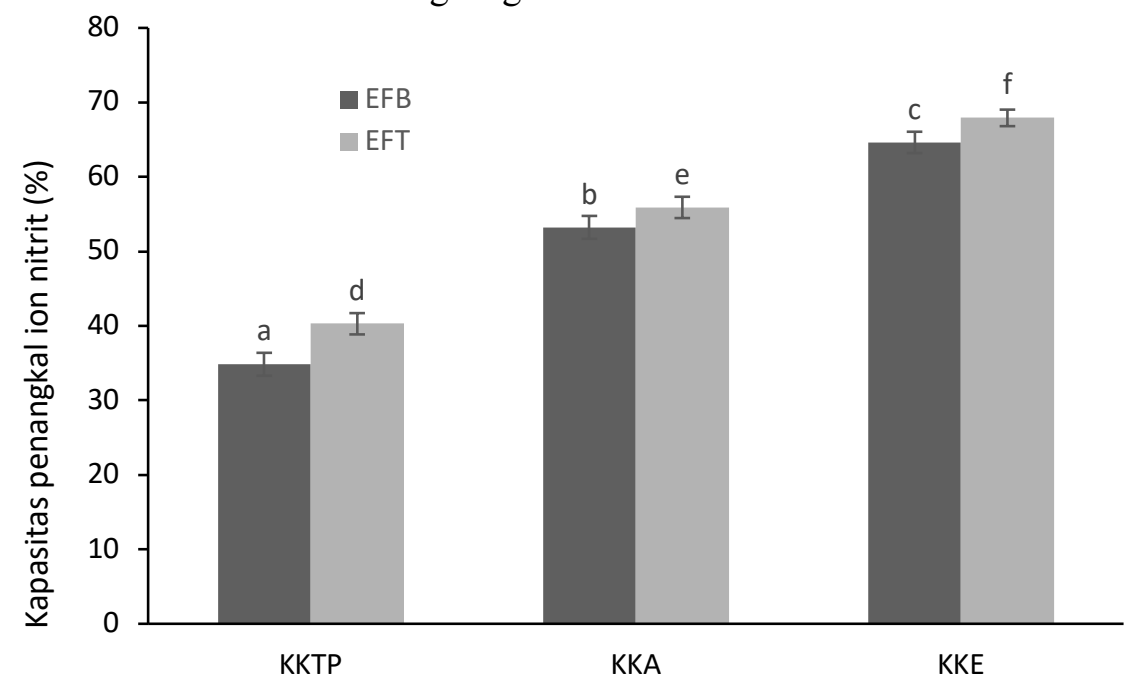

Tabel 4. Kapasitas penangkal nitrit ekstrak fenolik bebas (EFB) dan ekstrak fenolik terikat (EFT) dari tepung kulit kakao KKTP, KKA dan KKE (Singkatan seperti pada Tabel 1.)

Berdasarkan Tabel 6, menunjukkan bahwa kapasitas penangkal nitrit tertinggi untuk fenolik terikat terdapat sampel KKE sebesar $(67,92 \%)$, kemudian diikuti KKA sebesar $(55,90 \%)$ dan yang terendah terdapat pada sampel KKTP sebesar $(40,28 \%)$. Sedangkan untuk ekstrak fenolik bebas kapasitas penangkal nitirit tertinggi terdapat pada sampel KKE sebesar $(64,63 \%)$, kemudian diikuti KKA sebesar $(53,22 \%)$, dan yang terendah terdapat pada sampel KKTP $(34,84 \%)$. Hal ini kemungkinan dipengaruhi oleh kandungan senyawa fenolik pada masing-masing ekstrak. Hal ini sesuai dengan beberapa penelitian yang menunjukkan adanya hubungan yang kuat antara kandungan total fenolik dengan kapasitas penangkal nitrit dari berbagai ekstrak tanaman (Nova dkk., 2020; Dareda dkk., 2020; Karepu dkk., 2020).

\section{KESIMPULAN}

Karakterisasi secara fisik dengan XRD menunjukkan derajat kristalinitas KKTP lebih tinggi daripada KKA dan KKE. Analisis spektrofotometer FTIR antara KKTP, KKA dan KKE menunjukkan tidak ada perubahan mendasar pada komponen utama setelah dimikronisasi dan proses ekstraksi. Karakterisasi secara kimia menunjukkan kandungan air KKTP lebih tinggi dari KKA dan KKE, kandungan protein, karbohidrat dan lignin KKA lebih tinggi dari KKTP dan KKE. Sedangkan kandungan abu, lemak, serat pangan tak larut, serat pangan terlarut, total serat pangan, hemiselulosa dan selulosa KKE lebih tinggi dari KKTP dan KKA. Aktivitas antioksidan menunjukkan bahwa untuk ekstrak fenolik terikat KKE lebih tinggi daripada KKA dan KKTP. Hal ini juga diperlihatkan untuk ekstrak fenolik bebas KKE lebih tinggi daripada KKA dan KKTP.

\section{DAFTAR PUSTAKA}

Abbasi, M.A., Islam, M., Aziz-ur-Rehman, Rasool, S., Rubab, K., Hussain, G., Ahmad, I., Ahsraf, M., Shadid, M. \& Sha, S.A.A. 2016. Synthesis, characterization, antibacterial, $\alpha$-glucosidase inhibition and hemalytic studies on some new N-(2,3dimethylphenyl) benzene sulfonamide derivatives. Tropical Journal of Phamarceutical Research. 15(3), 591-598.

Badan Pusat Statistik.2020. Statistik Kakao Indonesia (Indonesian Cocoa Statistic). Jakarta: Badan Pusat Statistik. $V$

Balachandran, S., Kentish, S.E., Mawson, R. \& 
Ashokkumar, M. 2006. Ultrasonic enhancement of the supercritical extraction from ginger. Ultrason Sonochemistry. 13(6), 471-479.

Burda, S. \& Oleszek, W. 2001. Antioxidant and antiradical activities of flavonoids. Journal of Agricultural and Food Chemistry. 49(6), 2774-2779.

Byung, Y.C., Kenji, I. \& Kang Wan, H. 2003. Compositional characterization of cacao (Theobroma cacao L.). Journal of Agricultural Chemistry Biotechnol. 46(1), 12-16.

Chesson, A. 1978. The Maceration of linen flax under anaerobic conditions. Journal of Applied Bacteriology. 45(2), 219-230.

Dareda, C.T., Suryanto, E. \& Momuat, L.I. 2020. Karakterisasi dan aktivitas antioksidan serat pangan dari daging buah pala (Myristica fragrans Houtt). Chemistry Progress. 13(2), 48-55.

Datta, R. 1981. Acidogenic Fermentation of lignocelluloses acid yield and convertion of componens. Biotechnology and Bioengineering. 23(9), 2167-2170.

Departemen Perindustrian. 2007. Gambaran Sekilas Industri Kakao. Jakarta: Deperindag.

Hayati, R., Yusmanizar, Y., Mustafril, M., Fauzi, H. 2012. Kajian fermentasi dan suhu pengeringan pada mutu kakao (Theobroma cacao L.). Jurnal Keteknikan Pertanian. 26(2), 129-135.

Irwanto, D., Wiratni, R.\& Syamsiah, S. 2016. Pre-treatment dan fermentasi hidrolisat kulit buah kakao menjadi asam laktat menggunakan Lactobacillus Plantarum. Jurnal Reaktor 16(3), 123-127.

Janeiro, P. \& Brett, A.M.O. 2004. Catechin electrochemical oxidation mechanisms. Journal Analytica Chemica Acta. 518(12), 109-115.

Jeong, S. M., Kim, S. Y., Kim, D. R., Jo, S. C., Nam, K. C., Ahn, D. U. \& Lee, S. C. 2004. Effect of heat treatment on the antioxidant activity of extracts from citrus peels. Journal of Agricultural and Food Chemistry. 52(11), 3389-3393.

Karepu, M.G., Suryanto, E. \& Momuat, L.I. 2020. Komposisi kimia dan aktivitas antioksidan dari paring kelapa (Cocos nucifera). Chemistry Progress. 13(2), 39-47.

Ma, M. \& Mu, T. 2016. Modification of deoiled cumin dietary fiber with laccase and cellulase under high hydrostatic pressure. Carbohydrate Polymers. 136, 87-94.

Mason, T.J. 1990. Sonochemistry: The Use of Ultrasonic in Chemistry. Cambridge (UK): Royal Society of Chemistry.

Milovanovic, S., Markovic, D., Aksentijevic, K., Stojanovic, D.B., Ivanovic, J. \& Zizovic, I. 2016. Application of cellulose acetate for controlled release of thymol. Carbohydrate Polymers. 147, 344-353.

Momuat, L.I., Suryanto, E., Rantung, O., Korua, A. \& Datu, H. 2015. Perbandingan senyawa fenolik dan aktivitas antioksidan antara sagu baruk segar dan kering. Chemistry Progress. 8(1), 17-24.

Nova, Suryanto, E. \& Momuat, L.I. 2020. Karakterisasi fisikokimia dan aktivitas antioksidan serat pangan dari ampas empulur sagu baruk (Arenga Microcarpha B.). Chemistry Progress. 13(2), 22-30.

Noviyanti. 2016. Pengaruh Kepolaran pelarut terhadap aktivitas antioksidan ekstrak etanol daun jambu brazil batu (Psidium Guineense L.) dengan Metode DPPH. Jurnal Ilmiah Farmako Bahari. 7(1), 2935.

Nurhidayah, B., Eddy, S. \& Andi Evi, E. 2019. Kandungan kolagen sisik ikan bandeng (chanos-chanos) dan sisik ikan nila (Oreochromis niloticus). Jurnal Biologi Makassar. 4(1), 39-47.

Padilla, F. C., Ana, B. C. \& Isabel, A. 2015. Evaluacion de las propiedades antioxidantes calidad microbiologica de unexfoliante corporal a base de cascara de cacao (Theobroma cacao L.). Journal of revista Facultad de Farmacia. 78(2), 7176.

Padmawati, I.A.G., Suter, I.K. \& Arihantana, N.M.I.H. 2020. Pengaruh jenis pelarut terhadap aktivitas antioksidan ekstrak eceng padi (Monochoria vaginalis Burm F.C. Presel.). Jurnal Ilmu dan Teknologi Pangan. 9(1), 81-87.

Parra, L.D.C., Saldivar, S.O.S., Liu, H.R. 2007. Effect of processing on the photochemical profile and antioxidant activity of corn for production of masa, tortillas, and tortilla chips. Journal of Algicultural and Food Chemistry. 55(10), 4177-4183.

Pradana, P.F., Khoirul, M.D.D. \& Septian, E.A. 2017. The effectiveness test of ultrasonic extraction microwave distilalation method in capsaicin extraction. Journal of 
Engineering. 3(1), 6-10.

Raghavendra, S.N., Rastogi, N.K. \& Raghavarao, K.S.M.S. 2004. Dietary fiber from coconut residue: effects of different treatments and particle size on the hydration properties. European Food Research and Technology. 218(6), 563-567.

Rambat. Nurul, H. \& Bambang, R. 2015. Aplikasi limbah kulit kakao sebagai media fermentasi asam laktat untuk bahan baku bioplastik. Jurnal kimia kemasan. 37(2), 103-110.

Reddy, N. \& Yang, Y. 2005. Structure and properties of high quality natural cellulose fiber from cornstalks. Polymer (Guildf). 46(15), 5494-5500.

Sartini, Rangga, M.A. \& Ismail. 2017. Pengaruh pra perlakuan sebelum pengeringan sinar matahari dari kulit buah kakao terhadap kadar komponen fenolik dalam ekstrak. Jurnal Biologi Makassar. 2(1), 15-20.

Savjani, K.T., Gajjar, A.K. \& Savjani, J.K. 2012. Drug solubility: importance and enhacement techniques. International Scholarly Research Notices Pharmaceutics. 2012, 1-10.

Sediaoetama, A. D. 1985. Ilmu Gizi Jilid I. Jakarta: Dian Rakyat.

Sekarsari, S., I Wayan Rai, W.\& Agung, N.A.J. 2019. Pengaruh suhu dan waktu ekstraksi dengan gelombang ultrasonik terhadap aktivitas antioksidan ekstrak daun jambu biji (Psidium guajava L.). Jurnal Ilmu dan Teknologi Pangan. 8(3), 267-277.

Shanmugarajah, B., Kiew, P.L., Chew, I.M.L. \& Choong, T.S.Y. 2015. Isolation of nanocrystalline cellulose (ncc) from palm oil empty friut bunch (efb): preliminary result of ftir and dls analysis. Chemical Engineering Transactions. 45(2), 17051710.

Sholihah, M., Usman, A. \& I Wayan, B. 2017. Aplikasi gelombang ultrasonik untuk meningkatkan rendemen ekstraksi dan efektivitas antioksi dan kulit manggis. Jurnal Keteknikan Pertanian. 5(2), 161168.

Silfia, K., Diza, Y.H. \& Hermianti, W. 2017. Influence type of starter to increase efficiency of fermentation time and proximate analysis of cocoa seeds. Jurnal Litbang Industri. 7(1), 53-60.

Sudarmadji, 1997. Prosedur Analisa Untuk Bahan Makanan dan Pertanian. Yogyakarta: Liberty.
Suryanto, E. \& Suoth, E.J. 2020. Fitokimia II. Bandung: Patra Media Gravindo.

Suryanto, H. 2017. Analisis struktur serat selulosa dari bakteri. Prosiding Seminar Nasional Teknologi Terapan. 3(1), 1722.

Suryanto, E. \& Momuat, L.I. 2017. Isolasi dan aktivitas antioksidan fraksi dari ekstrak tongkol jagung (Zea mays). AGRITECH. 37(2), 139-147.

Trowell, H., Burkitt, D. \& Heaton, K. 1985. Definition of Dietary fibre and fibre depleted foods and diseases. London: Academic Press Ltd.

Troedec, M.L, Sedan, D., Peyratout, C., Bonnet, J.P. \& Agnes, S. 2008. Influence of various chemical treatments on the composition and structure of hemp fibres. Compos. 39(3), 514-522.

Vasquez, Z. S., Dao, P. C.N., Gilberto V.M., Luciana P.S. \& Priscilla, Z. 2019. Biotechnological approaches for cocoa. Journal of Waste Management. 90(2019), $72-83$

Wijaya, M.M., Muhammad, W. \& Muhammad A. 2017. Kandungan selulosa limbah kakao dan analisis kandungan kimia asap cair kulit kakao dengan metode GC-MS. Jurnal Kimia Dan Pendidikan Kimia 2(3), 191197.

Winarno, F.G. 1992. Kimia Pangan dan Gizi. Jakarta: Gramedia Pustaka Utama.

Xia, T., Siquan, S., Xiaochun, W. 2006. Impact of ultrasonic-assisted extraction on the chemical and sensory quality of tea infusion. Journal of Food Engineering. 74(4), 55-60.

Yenrina, R. 2015. Metode Analisi Bahan Pangan dan Komponen Bioaktif. Padang: Andalas University Press.

Yoshito, I. 2006. Tissue Engineering Fundamental and Application. California: Academic Press.

Zhang, L., Xu, H. \& Li, S. 2009. Effects of micronization on properties of Chaenomeles Sinensis (Thouin) Koehne Fruit Powder. Innovative Food Science \& Emerging Technologies. 10(4), 633-637.

Zhao, X., Zhu, H., Zhang, G. \& Tang, W. 2015. Effect of superfine grinding on the physicochemical properties and antioxidant activity of red grape pomace powders. Powder Technology. 286(8), 838-844. 